\title{
Survey on awareness and knowledge of farmers about plaguesome alien weed Parthenium hysterophorus in Sagar district of Madhya Pradesh
}

\author{
P. K. MISHRA*, VINITA PARTE AND GHANSHYAM JAMLIYA
}

Department of Agronomy, J.N.K.V.V., College of Agriculture, Ganjbasoda, VIDISHA (M.P.) INDIA

\section{ARITCLE INFO}

Received : 26.07 .2017

Revised : 02.09 .2017

Accepted : 14.09 .2017

\section{KEY WORDS :}

Parthenium, Awareness, Knowledge, Ill effects, Dissemination

*Corresponding author:

Email : mailsonumishra@gmail.com

\begin{abstract}
:
A survey on awareness and knowledge of Parthenium infestation was conducted in Jaisi nagar block of Sagar district of Madhya Pradesh. The survey indicated that 54 per cent respondents were getting information about Parthenium from relatives and neighbors, 40.86 per cent respondents reported ill effects of Parthenium on human beings. About the method of Parthenium control, 60.86 per cent and 16.57 per cent of the respondents adopted manual and chemical method, respectively.
\end{abstract}

How to view point the article : Mishra, P.K., Parte, Vinita and Jamliya, Ghanshyam (2017). Survey on awareness and knowledge of farmers about plaguesome alien weed Parthenium hysterophorus in Sagar district of Madhya Pradesh. Internat. J. Plant Protec., 10(2) : 389-392, DOI : 10.15740/HAS/IJPP/10.2/389-392. 